\title{
Teacher Collaboration as a Mediator for Strategic Leadership and Teaching Quality
}

\section{Siti Noor Ismail}

Dr., School of Education, Universiti Utara Malaysia, 06010 Sintok, Kedah, Malaysia, siti.noor@uum.edu.my

\section{Fazleen Muhammad}

School of Education, Universiti Utara Malaysia, 06010 Sintok, Kedah, Malaysia, delihonda@yahoo.com

\author{
Abdul Ghani Kanesan \\ Prof., School of Education, Universiti Science of Malaysia, Penang, Malaysia, \\ agk@usm.my
}

\author{
Aizan Yaacob \\ AP., School of Education, Universiti Utara Malaysia, 06010 Sintok, Kedah, Malaysia, \\ aizan904@uum.edu.my
}

\begin{abstract}
The objective of the present study was to determine whether teacher collaboration is a mediator of the strategic leadership and teaching quality in schools. This study involved 300 teachers in the high prestige secondary schools in Kelantan, Malaysia, whereby a cross-sectional survey approach using a standard questionnaire was used. The strategic leadership instrument used has been adapted from Hairuddin Ali (2012), while the collaborative instrument has been adapted from Barkema and Moran (2013). In addition, to measure the teaching quality among teachers, the researcher adapted the questionnaire that has been developed by Shahril Marzuki (2005). The findings from multiple regression analysis show that teacher collaboration is a mediator of strategic leadership and teaching quality $(\mathrm{B}=0.14, \mathrm{p}<.05)$. It was recommended among others that the school leaders should continue to strengthen collaborative practices among teachers as an effort to improve teaching quality in their respective schools which in turn will help to improve school excellence, especially across the current era of globalization.
\end{abstract}

Keywords: strategic leadership, teacher collaboration, teaching quality, high prestige secondary schools, strategic leadership, mediator

Citation: Ismail, S. N., Muhammad, F., Kanesan, A. G., Yaacob, A., \& (2018). Teacher Collaboration as a Mediator for Strategic Leadership and Teaching Quality. International Journal of Instruction, 11(4), 485-498. https://doi.org/10.12973/iji.2018.11430a 


\section{INTRODUCTION}

School is a formal organization that provides education to individuals called students who will lead the country in the future. This is in line with the National Education Philosophy that education in Malaysia is a continuous effort to produce balanced individuals in terms of physical, emotional, spiritual and intellectual needs and these individuals are expected to contribute to their families, communities and countries in the future. Thus, a school needs a charismatic leader to lead the institution. To ensure the quality of education is further enhanced, the government has launched a more robust educational plan, the Malaysian Education Development Plan (MEDP) 2013- 2025. In this plan there are eleven (11) shifts listed. One of the shifts in this plan relates to leadership in the school which is the fifth shift (5) MEDP. Through this shift, the government will ensure that distributed leadership style is practiced in every school.

In addition to the two types of leadership styles mentioned in MEDP 2013-2025, there is another leadership style that can have a positive impact on the school namely strategic leadership (Hairuddin Mohd Ali \& Aniyath Ali, 2015; Mariam Md Saleh, 2009; Mua'azam Mohamad, Yahya Don, \& Siti Noor Ismail, 2016). Meanwhile, Manish (2014) in her study stated that strategic leadership visions and missions will only be achieved with the cooperation of management and organizer of an organization. This is also equivalent and coincides with the aspiration of the government who wants leadership in the school to be assisted by the middle level leaders. However, the issue here is why the strategic leadership style is not mentioned in MEDP 2013-2025 as the distributed leadership style and instructional leadership style? And does this leadership style affect the performance of teachers and staff in the school, in particular the aspect of collaboration and teaching quality?

Furthermore, under the agenda of teachers and school leaders in MEDP 2013-2025 the government has also identified the best way to improve classroom teaching and learning which is through observations from the head of the field or senior teachers or principals of their supervised teachers. Collaboration or work in groups among teachers is also a major contributor to helping improve teachers' achievement including the quality of their teaching (Berry \& Daughtrey, 2009; Killion, 2015). Reports obtained from the first wave implementation of MEDP (2013- 2025) in 2015 have shown that the Ministry has expanded the Profesional Learning Community (PLC) program or more precisely the collaboration between teachers to 356 new schools across the country and bringing the total number of schools implementing the program to 1548 since 2011.

This clearly demonstrates the collaboration practices that governments have implemented, have resulted in success. However, the study conducted by Mohammed Sani Ibrahim (2013) states that working in and as a team among teachers can only occur when there is a cohesive or good relationship among them. This statement is also supported by Fapohunda (2013) who stated that this group's work would not achieve its goal when their team was not fully trusted to make a decision. Thus, this study was conducted to identify whether teacher's collaboration acts as a mediator on the strategic leadership and teaching quality. 
Teaching quality is a quality in teaching and learning process that needs to be made on the basis of disseminating knowledge (Sakarneh, 2014). Literature review shows that the teaching quality implicates the achievement of students (Ngware, Ciera, Musyoka, \& Oketch, 2015; Quint, Akey, Rappaport, \& Willner, 2007; Seebruck, 2015). This suggests that teaching quality is also geared towards helping students to improve their achievement especially in the academic field. However, teaching quality will only occur with the presence of quality teachers who have gone through effective recruitment and training programs (Courtney, 2016; Greatbatch \& Holland, 2016).

In MEDP 2013- 2025 with respect to the teaching quality, there is a difference in opinion regarding the teaching quality between the Inspectorate and the Quality Assurance (JNJK) and schools. For example, the data obtained by the School Inspector is only $13 \%$ for the teaching quality, but the percentage provided by the school is $63 \%$. The difference in this data shows that more efforts need to be made to improve teachers' pedagogical skills so that they can improve the quality of their teaching. Meanwhile, studies conducted by the Higher Education Leadership Academy (AKEPT) 2011 show that only $12 \%$ of the teaching is delivered at high standards, while $38 \%$ are in satisfactory standards and $50 \%$ are at an unsatisfactory level. Based on the above discussion, this study was conducted to identify whether teacher collaboration is a mediator of the strategic leadership and teaching quality at the high prestige secondary schools.

\section{THEORETICAL BACKGROUND}

\section{Strategic Leadership Model}

This study used a strategic leadership model developed by Davies and Davies (2004). This model is divided into two (2) main components namely organizational capability and individual characteristics. Through this strategic leadership model, a leader should apply nine (9) strategic leadership elements that have been listed by Davies and Davies (2004) under the organizational capability components and individual characteristics. The elements are;- a) strategic orientation, b) strategic translation, c) strategic alignment, d) strategic intervention, e) strategic capability, f) anxiety, e) absorption, g) adaptation and $\mathrm{h}$ ) wise

In their journals titled Strategic Leadership, Davies and Davies (2010) explain how to get effective strategic leadership. According to them, if leaders support strategic leadership practices to be implemented in schools, they need to be able to build a framework for understanding with this strategic leadership. In line with that, there is an organizational capability component and individual characteristics that they think can be attributed to strategic leadership.

Under the organizational capability components, there are five (5) elements that must be probed by a leader to achieve effective strategic leadership practices: a) strategic orientation, b) strategic translation, c) strategic alignment, d) strategic intervention, and e) strategic capability. On the other hand, under the individual characteristic components, there are four (4) elements that need to be applied by a leader, that are a) 
anxiety, b) absorption, c) adaptation and d) wise. The strategic leadership model produced by Davies and Davies (2004) is as follows: -
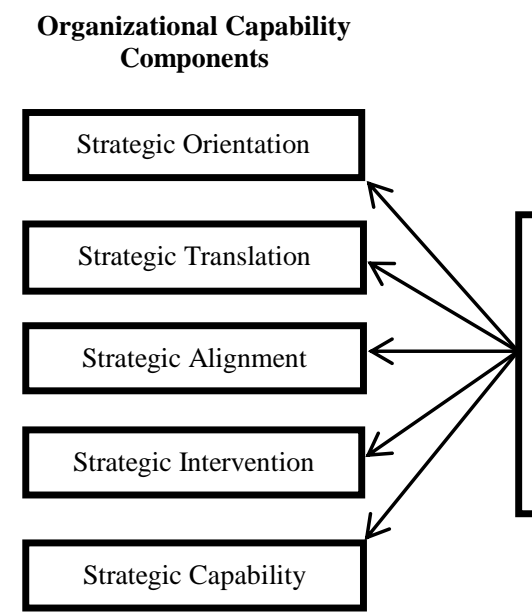

Individual Characteristic

Components

Figure 1

Strategic Leadership Model (Sources: Davies \& Davies, 2004)

\section{The Theory and Concept of Collaboration}

Collaboration is a variable that can determine the teaching quality at school and also one of the reasons for the excellence of a school. Collaboration in this context refers to collaboration between teachers or between administrators and teachers working in groups with the aim of helping together to improve their school's performance excellence. According to Wan Idros Wan Sulaiman and Maizatul Haizan Mahbob (2012), collaboration refers to a close relationship between top management and subordinate management or in other words, the administration and employees who will be the trigger for the success of an organization. So, in short, collaboration is a close relationship between school makers who can help improve the performance of a school.

Communication, co-operation and coordination are three-dimensional collaborations that have been described in the journal "The Three C's Of Team-Building Communication, Cooperation, Coordination" (Thomas, Morin, Kira, 2016). The study was conducted to look at the different skills requirements in the course conducted online as a whole, the perceptions of students on working skills in the team as used in Business Statistics courses conducted in regular classes. Next, Thomas, Morin and Kira (2016), have found that the course content that requires building a team in a virtual or remote environment is not easy to implement as a regular class. The conclusions that can be made from this study are the cohesion or the close relationship that is important in establishing this collaborative practice. Remote distances and relationships within the virtual world or online do not help in establishing this collaborative practice. 
This study uses the Tuckmans (1965) group collaboration or work model that has four (4) stages, forming, storming, norming and performing (Tuckman, 1965; Tuckman \& Jensen, 1977). At the beginning of the establishment of a group or forming of each member will meet and identify with respect to opportunities and challenges and then agree on the goals and begin to look for ideas and understand about the task entrusted (Fapohunda, 2013). In this initial stage, team leaders or supervisors play a very important role and should always supervise their group. This initial stage is very important because at this time the members of the group meet with each other, they will also get acquainted with each other, exchange their own information and find new friends or those who can share their ideas with them. This is also an opportunity for supervisors or team leaders to see how their group members will act as a true individual and how members of the group face pressure from the group.

While in the second stage, the storming, according to Tuckman (1965), each member will throw their ideas and compete so that their ideas will be accepted and adopted to complete the task given to their group. According to him, some groups will leave this stage quickly and a handful will continue the commotion in the debate of this idea for a long period of time. Hence, here is the maturity and effective communication of some team members or group leaders will play a role to resolve the idea conflict among their group members and help remove the group from this stage immediately (Wan Idros Wan Sulaiman \& Maizatul Haiza Mahbob, 2012).

The third stage is norming, or norm. At this stage, the team has a common goal and plan to complete the assignment given (Fapohunda, 2013). Members of the group also have to agree on the ideas received by other members and begin to mobilize the group's function. They will also take their responsibilities and start working to achieve the goals set by the group. Performing or presenting is the last stage in the Tuckman group model. At this stage, team members are now more competent, capable and able to handle the decision-making process unattended. High-performing teams can function as units as they can find a way to complete the task properly (Rebecca Nestor, 2013) and effectively without conflicts that do not fit or require oversight from outside parties.

\section{Theory and Concept of Teaching Quality}

The teaching quality or teaching effectively focuses on the process of achieving success in students learning expected through educational activities (Mohammed Sani Ibrahim, 2013). According to Shahril Marzuki (2005), effective teaching practice is that when a teacher is able to diversify teaching methods, provide teaching aids and deepen the content to be taught. In short, it can be said that the quality of this teaching is about how teacher can apply the teaching process effectively through the identified techniques.

Teaching quality in NSW public schools has set up three (3) essential elements that teachers should take to achieve good teaching quality standards (Gore, Ladwig, Wendy, \& Hywel, 2003). These elements are intangible quality, quality learning environment and the importance of learning. According to Mohammed Sani Ibrahim (2013), two important dimensions to ensure that teaching can be implemented with quality is first by looking for the best strategies to plan subjects, or holding team meetings so that they are constantly managing time to focus on teaching and learning issues, and the second is 
finding ways to allow teachers to teach in teams and to look into their respective lessons in the classroom so they can share ideas and promote collaborative culture. There are six (6) components to produce teaching quality that are; knowledge, teaching quality, class climate, class management, teacher confidence and professional attitude (Coe, Aloisi, Higgins, \& Major, 2014).

However, this study uses the model of teaching quality introduced by Slavin (1994) which is an effective teaching model consisting of four (4) dimensions, namely quality of instruction, appropriate level of instruction, incentive, and time for instruction. The teaching quality dimension covers how teacher tries to make their teaching effective in any subject, by mastering a lot of knowledge and understanding of teaching (Mohammed Sani Ibrahim, 2013). Whereas for the dimensions of the teaching-level compatibility, referring to the level of teaching is appropriate to the ability and capabilities or interests of students (Courtney, 2016).

Furthermore, the incentive dimension refers to how teacher can motivate the students to learn and complete the assignment. Slavin (1995) states that two ways can be used to motivate a student by diversifying the teaching method and the second is to reward or reward the appropriate student. Finally, the dimensions associated with the time allocation for teaching are the time allocated for a student to master a lesson that has been taught. Shahril Marzuki (2005) explains, the allocation of time for teaching is divided into two that is the time allocated, the time determined by the school for the teacher to perform the teaching and time on task or the time spent on the teacher's time performing lessons and time for a student to master what the teacher is teaching.

\section{Rationale of the Study}

The studies discussed in the above section have acknowledged the role of strategic leadership (Hairuddin Mohd Ali \& Aniyath Ali, 2015; Mariam Md Saleh, 2009; Mua'azam Mohamad, Yahya Don, \& Siti Noor Ismail, 2016; Manish, 2014), and also teacher collaboration as a catalyst for teaching quality in schools. However, how far does this leadership style affect the performance of teachers and staff in the school, in particular the aspect of collaboration and teaching quality? Also, is it teacher collaboration act as a partial or full mediator towards teaching quality? So, it needs to be explored. Therefore, a justifiable need was felt to conduct a separate study on the role of teacher collaboration towards strategic leadership and teaching quality. The results of the study would be useful for an administrators, school leaders, teachers and stakeholders in order to ensuring the excellence of education can be achieved successfully

\section{Research Question \& Hypothesis}

The following research questions were raised to guide the conduct of the study;

RQ: Is teacher collaboration a mediator to the strategic leadership and teaching quality?

Based on the above research questions, the hypothesis of the study was formed:-

Ho: Teacher collaboration is not a mediator to the strategic leadership and teaching quality. 


\section{METHOD}

\section{Research Design}

The research design adopted for this study was descriptive survey by using the multiple regression method. This method is used to examine the effect of teacher collaboration on their teaching quality, whether teacher collaboration is a mediator to the strategic leadership and teaching quality. Through this analysis, researchers use theories and concepts presented by Baron \& Kenny (1986). Data obtained from quantitative methodology is systematic, uniform and easy to be presented (Patton, 2002).

\section{Population and Sampling}

The target population for this study comprised all teachers from high prestige schools in Kelantan, east part of Malaysia by using a cluster sampling technique. This sampling technique is used in a situation where the population members are naturally grouped into a unit that can be conveniently used as clusters (Sekaran, 2003). High prestige schools are chosen because it is a school with an ethos, character, and distinctive identity and unique in all aspects of education and able to be competitive in the world. A sample of 300 teachers was selected from five (5) high prestige secondary schools. Teachers from the schools involved were selected at random.

\section{Data Collection Tools}

This study employed a standard questionnaire which consists of four (4) parts, namely A, B, C and D. Part A contains the respondents' background, Part B contains relevant items on strategic leadership level, part $\mathrm{C}$ contains items related to collaboration and section D contains items related to teaching quality. In this study, a questionnaire on strategic leadership has been adapted from Hairuddin Ali (2012). The instrument 'Scoring the Tuckman Team Maturity Questionnaire Electronically' to measure collaboration was adapted from Barkema and Moran (2013) and to measure teaching quality, researchers have adapted the questionnaires 'Effective Teaching based on Slavin Model' that have been developed by Shahril Marzuki (2005).

All the instruments conform to the theory of leadership, collaboration and teaching quality besides following the principles of building items in terms of validity and consistency. The internal consistency of these three instruments is estimated by calculating the reliability coefficient, $\alpha$. The result of the reliability analysis for these three instruments demonstrated very high reliability. The Cronbach alpha value for each instrument is between 0.84 and 0.96 . The scores for these three instruments have a very good reliability coefficient of more than 0.80 (Ary, Jacobs \& Razavieh, 2002). The measurement for each variable is to use a five-point scale.

\section{FINDINGS}

\section{Profile of the Respondents}

Table 1 indicates the respondents' profile by gender, age and field of teaching. The findings show that the respondents comprised $174(58.00 \%)$ female and $126(42.00 \%)$ 
male teachers with the age ranged between 20 to 59 years old. The majority came from over 40 years old age groups. In terms of field of teaching, there were $96(32.00 \%)$ teach Science \& Mathematics, Language, 94 (8.44\%) Social Science/Humanities, 92 $(30.67 \%)$ and $18(6.00 \%)$ for Technic \& Vokasional.

Table 1

Respondents by Gender, Age, Ethnic and Field of Teaching (N=300)

\begin{tabular}{llll}
\hline Demographic Information & Categories & $\mathrm{N}$ & $\%$ \\
\hline Gender & Male & 126 & 42.00 \\
Age & Female & 174 & 58.00 \\
& $50-59$ & 77 & 25.70 \\
& $40-49$ & 101 & 33.70 \\
\multirow{3}{*}{ Field of Teaching } & $30-39$ & 76 & 25.30 \\
& $20-29$ & 46 & 15.30 \\
& Science \& Mathematics & 96 & 32.00 \\
& Language & 94 & 31.33 \\
& Social Science/Humanities & 92 & 30.67 \\
& Technic \& Vokasional & 18 & 6.00 \\
\hline
\end{tabular}

Research Questions: $\quad$ Is teacher collaboration a mediator to the strategic leadership and quality teaching?

This study has used regression analysis to analyze the mediators involved and researchers have used the theory and concept of mediators as highlighted by Baron and Kenny (1986). According to them, mediators are an intermediary variable that can affect dependent variables and appropriate analysis to test this mediator is to use multiple regressions. Mediators model as they have produced are as follows:-

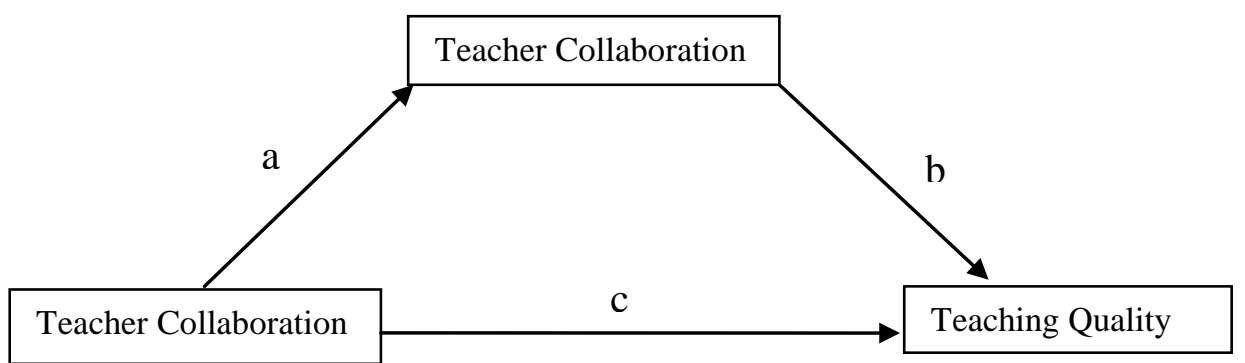

Figure 2 Mediator Model (Baron \& Kenny, 1986)

This analysis involves four regressions that are carried out to test the effect of teacher collaboration mediators on strategic leadership and teaching quality. The first regression is the regression of strategic leadership towards teaching quality, for the purpose of path c. Regression analysis results show that unstandardised regression coefficient $B$ equals 0.26 with $\mathrm{p}<0.00$ and satisfies the conditions of mediation, as shown in Table 1. 
Table 1

Test for path c - strategic leadership on teaching quality

\begin{tabular}{lcccc}
\hline Variable & $\mathrm{B}$ & $\beta$ & $\mathrm{t}$ & $\mathrm{p}$ - value \\
\hline Constant & 3.27 & & 18.91 & 0.00 \\
Strategic Leadership & 0.26 & 0.33 & 6.02 & 0.00 \\
\hline
\end{tabular}

$\mathrm{R}=0.33$

$\mathrm{R}^{2}=0.12$

$\mathrm{R}^{2}$ adjusted $=0.11$

Standard Error $=0.43$

Dependent variable: Teaching Quality

The second regression is the regression of the independent variables (strategic leadership) against mediator variable (teacher collaboration) for the purpose of studying whether path a, is significant. The findings show that strategic leadership has a significant relationship with teacher collaboration. Regression results provide a value of $\mathrm{B}$ equals 0.32 with $\mathrm{p}<0.00$. This means that strategic leadership is a significant predictor of teacher collaboration. The beta value equivalent to 0.43 illustrates that when strategic leadership is increased by one standard unit, teacher collaboration will also increase by 0.43 standard units. This finding as in Table 2 further demonstrates that path a in this series of analysis is significant. Therefore, path qualifies for mediation.

Table 2

Test for path a - strategic leadership on teacher collaboration.

\begin{tabular}{lcccc}
\hline Variable & $\mathrm{B}$ & $\beta$ & $\mathrm{t}$ & $\mathrm{p}$-value \\
\hline Constant & 2.35 & & 15.25 & 0.00 \\
Strategic Leadership & 0.32 & 0.43 & 8.28 & 0.00 \\
\hline
\end{tabular}

$\mathrm{R}=0.43$

$\mathrm{R}^{2}=0.19$

$\mathrm{R}^{2}$ adjusted $=0.18$

Standard Error $=0.38$

Dependent variable: Teacher Collaboration

The third regression analysis was carried out for the purpose of detecting path $b$, the regression of mediator variable (teacher collaboration) on dependent variable (teaching quality). The regression results show that $\mathrm{b}$ is significant $(\mathrm{B}=0.47, \mathrm{p}<0.00)$ as shown in Table 3.

Table 3

Test for path $\mathrm{b}$ - teacher collaboration on teaching quality

\begin{tabular}{lcccc}
\hline Variable & $\mathrm{B}$ & $\beta$ & $\mathrm{t}$ & $\mathrm{p}$-value \\
\hline Constant & 2.61 & & 12.88 & 0.00 \\
Teacher Collaboration & 0.47 & 0.44 & 8.33 & 0.00 \\
\hline
\end{tabular}

$\mathrm{R}=0.462$

$\mathrm{R}^{2}=0.213$

$\mathrm{R}^{2}$ adjusted $=0.208$

Standard Error $=0.402$

Dependent variable: Quality teaching 
This shows that there is a significant relationship between teacher collaboration and teaching quality (path b). Therefore, the third condition of mediation is fulfilled.

For path c', the regression of the strategic leadership on teaching quality when teacher collaboration is controlled. Regression analysis results show that unstandardized regression coefficient $\mathrm{B}$ equal to 0.14 with $\mathrm{p}<0.05$. Therefore, this study has shown that path $\mathrm{c}^{\prime}$ in this analysis series is significant.

Table 4

Test for path c' - strategic leadership on teaching quality when teacher collaboration is controlled

\begin{tabular}{lcccc}
\hline Variable & $\mathrm{B}$ & $\beta$ & $\mathrm{t}$ & $\mathrm{p}$-value \\
\hline Constant & 2.36 & & 10.89 & 0.00 \\
Strategic Leadership & 0.14 & 0.17 & 3.04 & 0.00 \\
Teacher Collaboration & 0.39 & 0.36 & 6.30 & 0.00 \\
\hline
\end{tabular}

$\mathrm{R}=0.462$

$R^{2}=0.213$

$\mathrm{R}^{2}$ adjusted $=0.208$

Standard Error $=0.402$

Dependent variable: Teaching Quality

The result of all the multiple regression analysis results conducted to examine the teacher collaboration function as a mediator towards the strategic leadership and teaching quality is shown in Table 5.

Table 5

Teacher Collaboration Mediator Impact Towards The Strategic Leadership and Teaching Quality

\begin{tabular}{lcccccc}
\hline Multiple Regression & B & Standard Error B & $\beta$ & $95 \%$ CI & t & p \\
\hline Path c & 0.26 & 0.04 & 0.33 & $(0.17,0.34)$ & 6.02 & 0.00 \\
Path a & 0.32 & 0.04 & 0.43 & $(0.24,0.39)$ & 8.28 & 0.00 \\
Path b & 0.47 & 0.06 & 0.44 & $(0.36,0.58)$ & 8.33 & 0.00 \\
Path c' & 0.14 & 0.05 & 0.17 & $(0.27,0.51)$ & 3.04 & 0.00 \\
\hline
\end{tabular}

Table 5 shows the significant impact of strategic leadership variables on the teaching quality without the presence of teacher collaboration variable mediators $(B=0.26 ; \mathrm{p}$ $<0.05)$, and also significant with the presence of teachers' collaboration variable $(\mathrm{B}=$ $0.14 ; p<0.05)$, but the value of beta coefficient ( $(B)$ decreases $(\beta=0.33$ to $\beta=0.17)$. Therefore, teacher collaboration acts as a partial mediator on the relationship between strategic leadership and the teaching quality.

In summary, there are four steps taken by the researchers based on the guidance provided by Baron and Kenny (1986) to prove that teacher collaboration has mediator influence on strategic leadership relationship with the teaching quality. The four conditions that must be followed as the guidelines used are as follows: -

I. First step, independent variable (strategic leadership) must affect the dependent variable (quality teaching). 
II. The second step, independent variable (strategic leadership) must affect the mediator variable (teacher collaboration).

III. Third step, the mediator variable (teacher collaboration) must affect the dependent variable (teaching quality).

IV. Fourth step, compare the effects of independent variable (strategic leadership) on dependent variable (teaching quality) with the presence or absence of mediator variable (teacher collaboration). If the three conditions mentioned above are in a positive or negative state as determined, the effect of the independent variable (strategic leadership) without the mediator and with the mediator (teacher collaboration) is significant and the beta value of the coefficient $(\beta)$ decreases so the mediator is partial. This implies a direct impact along with the impression of the mediator. Conversely, if the independent variable (strategic leadership) without the mediator (teacher collaboration) is significant and if the mediator is not significant and the beta coefficient $(\beta)$ decreases, then the full mediator applies. This implies that the immediate effect that existed would not appear when the mediator was introduced in the model. According to Mathieu and Taylor (2006), if the independent variable with the mediator and without the mediator is significant but the beta value of the coefficient $(\beta)$ increases, then the mediator does not exist.

Hence, it can be concluded that teacher collaboration is a partial mediator to the strategic leadership and teaching quality, as the conditions provided by Baron and Kenny (1986). This is because the three conditions mentioned above are in the positive state as determined and the effects of independent variable (strategic leadership) without the mediator and with the mediator (teacher collaboration) are significant and the beta coefficient $(\beta)$ value decreases. As such, it has a direct impact with the impression of the mediator.

\section{CONCLUSION}

Effective leaders need to ensure that their organization is in conducive environment, culture and climate that can enhance teacher behavior and teacher quality to a high level of quality services. So that, all the members in school organisation will proud to have teachers and school leaders who work together to achieve the goals set. Leaders also need to emphasize leadership practices effectively to influence teachers in accepting reforms in order to achieve mutual mission and vision (Geijsel, Sleegers, Leithwood \& Jantzi, 2003). According to Leithwood and Jantzi (2005), leadership in schools are able to improve the spirit of teachers when teachers show high commitment to their work. School leaders should also be aware that school leadership is not independent but requires a high spirit in teachers and good interactions among all members to achieve the goals set (Yangaiya, 2015). It's consistent with the findings of Wallace's (2013), who states that excellent school leadership was able to have a positive effect on the teacher's progress and thus improved the teaching quality.

The findings show that teacher collaboration is partial mediator to independent variable (strategic leadership) and dependent variable (teaching quality) based on the significant 
value of the $\mathrm{c}^{\prime}$ path $(\mathrm{p}<0.05)$. Collaborative functionality as partial mediators has also been proven when the findings of regression statistical analysis meet the specifics of partial mediator requirements as outlined by Zainuddin Awang (2015).

Based on the findings of this study, the null hypothesis in this study has been rejected because teachers' collaboration is seen to improve the teaching quality. This finding implies that the school leaders plan and develop a more effective program in order to empower the collaboration among teachers so as to improve the teaching quality. This study has also proven that with the presence of collaboration among teachers, the teaching quality will increase as compared to practicing strategic leadership only.

Collaboration may build the knowledge base among teachers in a school or professional network, adding value to the education students receive. Studies show that students perform better on their tests when they attend schools characterized by higher levels of teacher collaboration, creating a tipping point for sustained school turnaround (Goddad, 2013). Teachers who have consistent opportunities to work with effective colleagues also improve in their teaching effectiveness.

The findings of this study are also parallel and consistent with the Strong Teams article, Strong School (Sparks, 2013) stating that collaboration helps in strengthening leadership as well as teaching quality in school. This finding confirms the importance of this teacher's collaboration in influencing strategic leadership that is said to be the cause for the improvement of teaching quality. In other words, the school leaders who demonstrate the strategic leadership practices in schools can lead to the creation of collaborative practice among teachers and thus help to improve the professional standards among them namely teaching quality. When the teaching quality can be enhanced, the student's academic achievement will also increase, as outstanding students are produced by outstanding teachers. Thus, education excellence can be achieved successfully.

\section{REFERENCES}

Barkema, E., \& Moran, J. W. (2013). Scoring The Tuckman Team Maturity Questionnaire Electronically. $\quad$ Retrieved from http://www.phf.org/resourcestools/Documents/Electronic_Tuckman.pdf

Baron, R. M., \& Kenny, D. a. (1986). The Moderator-Mediator Variable Distinction in Social The Moderator-Mediator Variable Distinction in Social Psychological Research: Conceptual, Strategic, and Statistical Considerations. Journal of Personality and Social Psychology, 51(6), 1173-1182. https://doi.org/10.1037/0022-3514.51.6.1173

Berry, B., \& Daughtrey, A. (2009). Collaboration: Closing the Effective Teaching Gap. Center for Teaching Quality, (December), 1-10. Retrieved from http://eric.ed.gov/ERICWebPortal/recordDetail?accno=ED509717\%5Cnhttp://files.eric. ed.gov/fulltext/ED509717.pdf

Courtney, B. (2016). The importance of " teacher quality" and "quality teaching " on academic performance, 6(1), 28-38. 
Fapohunda, T. M. (2013). Towards Effective Team Building in the Workplace. International Journal Of Education and Research, 1(4), 1-12. Retrieved from http://www.ijern.com/images/April-2013/23.pdf

Geijsel, F., Sleegers, P., Leithwood, K. \& Jantzi, D. (2003). Transformational leadership effects on teachers' commitment and effort toward school reform. Journal of Educational Administration, 41(3), 228-256.

Goddard, Y. \& Goddard, R. D. (2007, April). A theoretical and empirical investigation of teacher collaboration for school improvement and student achievement in public elementary schools. Teachers College Record, 109(4), 877-896

Greatbatch, D., \& Holland, J. (2016). Teaching Quality in Higher Education : Literature Review and Qualitative Research May 2016. Open Government Licence (OGL), (MAY), $73 . \quad$ Retrieved from https://www.gov.uk/government/uploads/system/uploads/attachment_data/file/524495/h e-teaching-quality-literature-review-qualitative-research.pdf

Hairuddin Mohd Ali. (2012). The quest for strategic Malaysian Quality National Primary School Leaders. International Journal of Educational Management, 26 (1), 83 -98 .

Hairuddin Mohd Ali, \& Aniyath Ali. (2015). Do strategic leadership and self efficacy among school leaders make a difference? Asian Social Science, 11(27), 219-234. https://doi.org/10.5539/ass.v11n27p219

Killion, J. (2015). High-quality collaboration benefits teachers and students-lessons from research Joellen Killion. Journal of Staff Development, 36(5), 62-64. Retrieved from https://learningforward.org/docs/default-source/jsd-october-2015/high-qualitycollaboration-benefits-teachers-and-students.pdf

Krejcie, R. V., \& Morgan D. W. (1970). Determining sample size for research. Education and psychological measurement, 30, 607 - 610 .

Leithwood, K. and Jantzi, D. (2005). A review of transformational school leadership research, 1996-2005. Leadership and Policy in Schools, 4(3), 177-199.

Malaysia Education Ministry. (2013). Malaysia Education Blueprint 2013 - 2025. Education, 27(1), 1-268.

Malaysia Education Ministry. (2015). Annual Report 2015 Malaysian Education Development Plan (MEDP) 2013- 2025. Education, 1-182.

Malaysia Education Ministry. (2017). Malaysian Education Quality Standards Wave 2. Education, 1-100.

Manish, K. (2014). Strategic Leadership Versus Traditional Organizational Management Today, 2(11), 1-9.

Mariam Md. Salleh, Mohammed Sani Ibrahim, \& Siti Rahayah Ariffin. (2009). Leadership and Strategic Management in MARA Educational Institution). Malaysian Educational Journal, 34(1), 219-233. 
Mathieu, J. E., \& Taylor, S. R. (2006). Clarifying conditions and decision points for mediational type inferences in Organizational Behavior. Journal of Organizational Behavior, 27(8), 1031-1056. https://doi.org/10.1002/job.406

Mohammed Sani Ibrahim. (2013). The Role of Senior Teachers of the Subjects in Enhancing the Quality Teaching Among Teachers. Asean Pacific Teaching \& Curriculum Journal, 28-41.

Mua'azam Mohamad, Yahya Don, \& Siti Noor Ismail. (2016). Strategic Leadership And Their Relationship With The Willingness of Organizational Change. Educational Leadership Journal, 3(2), 1-14.

Ngware, M. W., Ciera, J., Musyoka, P. K., \& Oketch, M. (2015). Quality of teaching mathematics and learning achievement gains: evidence from primary schools in Kenya. Educational Studies in Mathematics, 89(1), 111-131. https://doi.org/10.1007/s10649015-9594-2.

Nunnally, J. (1978). Psychometric theory. McGraw-Hill, New York, NY.

Quint, J., Akey, T., Rappaport, S., \& Willner, C. (2007). Instructional Leadership, Teaching Quality and Student Achievement Suggestive Evidence from Three Urban School Districts. Mdrc, (December). Retrieved from http://eric.ed.gov/?id=ED499788

Sakarneh, M. (2015). Articulation of Quality Teaching: A Comparative Study. Journal of Education and Training Studies, 3(1), 7-20. https://doi.org/10.11114/jets.v3i1.579

Seebruck, R. (2015). Teacher Quality and Student Achievement: A Multilevel Analysis of Teacher Credentialization and Student Test Scores in California High Schools, 5(July), 1-18.

Shahril Marzuki. (2005). Amalan Pengajaran Guru yang Berkesan: Kajian di beberapa Sekolah Menengah di Malaysia. Jurnal Fakulti Pendidikan Universiti Malaya, 1-14.

Sparks, D. (2013). Strong teams, strong schools, 34(2), 28-30.

Viadero, D. (2009). Top-notch teachers found to affect peers. Education Week.Retrieved September $\quad 1, \quad 2009$ at http://www.edweek.org/ew/articles/2009/09/01/03peer.html?tkn=VQ[F91pv4\%2Fm1H0 5QrumV3xEwIqnZkr5D18iG

Wallace Foundation. (2013). The school principal as leader: Guiding schools to better teaching and learning. Taken from October 6, 2015,

http://www.wallacefoundation.org/knowledge-center/school-leadership/effectiveprincipal-leadership/Documents/The-School-Principal-as-Leader-Guiding-Schools-toBetter-Teaching-and-Learning-2nd-Ed.pdf.

Yangaiya S. A. (2015). Distributed Leadership and Empowerment Influence on Teachers Organizational Commitment. Academic Journal of Interdisciplinary Studies MCSER Publishing, 4(1).

Zainuddin Awang. (2015). SEM made sample. A gentle to approach in learning structural equation modelling. Bangi: MPWS Rich Publication Sdn. Bhd. 